\title{
From 2000s to the Present, Analysis of Use of Portraits in Ex-libris Design
}

Ass. Prof. N. Irmak Akçadoğan Doğuş University, Faculty of Fine Arts and Design, Department of Graphics nakcadogan@dogus.edu.tr

Full Length Paper Accepted 10 January 2018

\section{Abstract}

From past to present, when examples of ex-libris are examined in the context of the items that constitute the artistic structure and function, it is seen that portraits are frequently used. The use of portrait is a method that does not easily fill in the expression and the inner depth in the background, although it seems to be the easiest approach to reflect the subject and the identity.

In accordance with data collected from the International Ex-libris Activities that became widespread in Turkey and the world, and with the analysis of the works in the ex-libris collections of various museums, this study aims to reveal the technological and formal differences of portrait usage that vary from country to country.

Key words: Ex-libris, Portrait, Art, Graphic Arts 


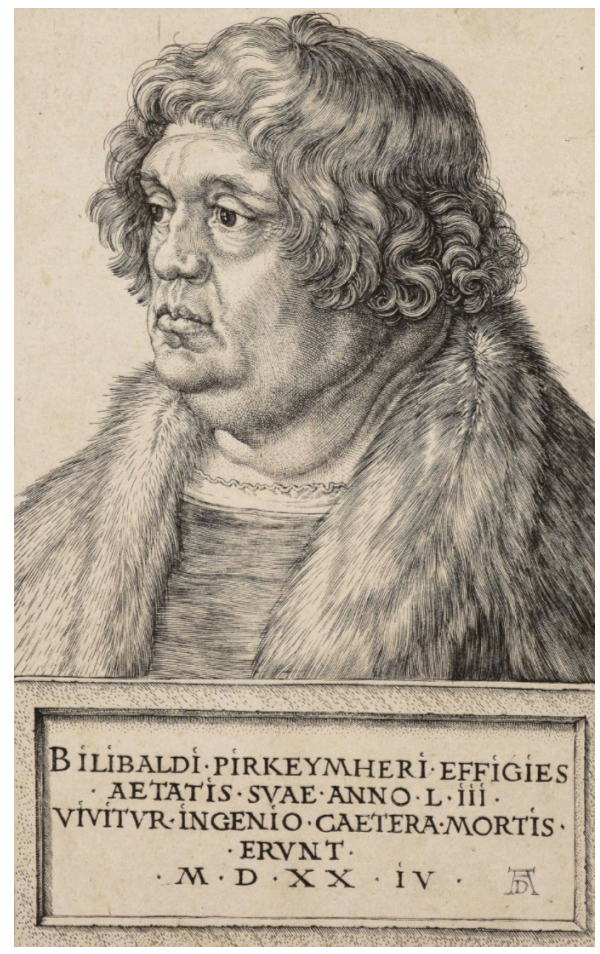

Figure 1: Albrecht Durer, 1524, Royal Collection, Engraving, 11, 4 × 8,0 cm, 1524 (Source: Royal Collection Trust/Her Majesty Queen Elizabeth II 2017)

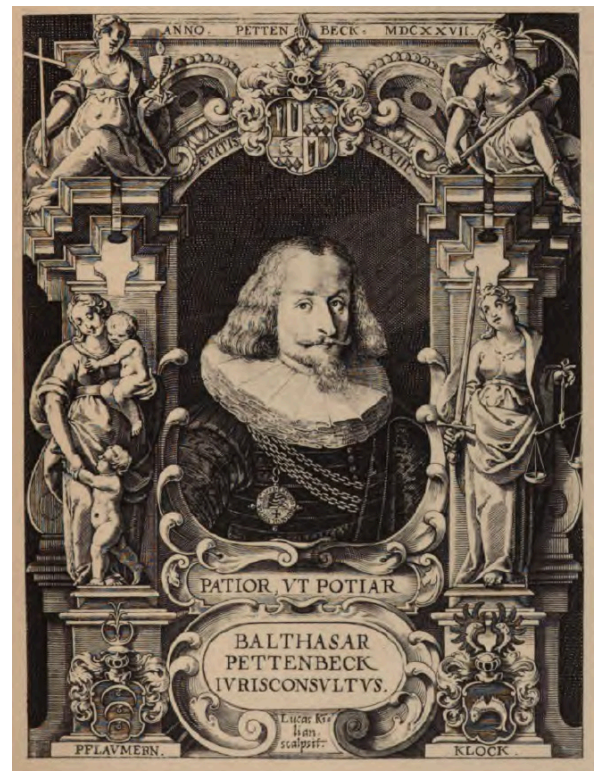

Figure 2: Designed for Balthasar Pettenbeck by Lucas Kilian in $1627,16,6 \times 12,3 \mathrm{~cm}, 1627$. (Source: The Ex-Libris Collection of the Ducal Library At Wolfenbüttel, London)
Ex-libris is an artistic interpretation of printed picture products that is affixed to the inside of books and expresses the identity of the book owner or a library. They are small in size because they are prepared by considering the book dimensions. These artistic creations, which serve as reminders for the return of books borrowed from personal libraries or libraries in general, introduce the owner of the book with original and creative expression language and technical approach of the artist who designed the book (Pektaş, 2017, p.11).

When examining the history of ex-libris, researchers point to one of the British Museum's collection items. The first and oldest ex-libris example appears to be a blue glazed small ceramic plate, which was estimated to have been attached to the wooden boxes that protected the papyrus rolls from $1400 \mathrm{BC}$ to indicate that they belonged to the Pharaoh Amenophis III library. In accordance with its present meaning and function, the first is exlibris specimens manufactured using wood printing technique were found in Germany 500 years ago, between the years 1470-1480 (Pektaş, 2017, p.13).

As a result of the invention of the printing press and the reproducibility of the books, the art of ex-libris developed in the 16th century and gained considerable demand. These rare artifacts, which contain all the subtleties of the artistic style of the period, were designed by respected original print artists for mostly famous lawyers, writers, statesmen, scientists, doctors and libraries.

From the 16th century onwards, the mastery of portrait use and the exlibris piece made for Willibald Pirckheimer in 1524 by Albrecht Durer, a leading artist from the era, using the engraving technique are remarkable (Pektaş, 2017, p.16). Expression in the figurative narrative has been depicted meticulously, requiring great artistic mastery. The artist has skillfully illustrated the Renaissance German humanist writer and lawyer Willibald Pirckheimer with the natural look in his eyes, and the details of his garment together with the effect of light. (See figure 1).

With the use of portraits, the work of the 17th-century German engraving artist Lucas Kilian (1579-1637) comes up in accordance with all the glory of the Baroque period. The portrait, which was designed by Lucas Kilian for the lawyer Balthasar Pettenbeck in 1627 with the dimensions of $16.6 \times 12.3$ $\mathrm{cm}$, is depicted in great detail. The period's decorative style and symbolic expressions in eclectic form are placed symmetrically on the work. Drawings of sculptures detailed with a unique and dazzling craftsmanship and heraldry of the nobility were emphasized with contrast. The writing, which is the most important element that provides functionality to ex-libris, was included 


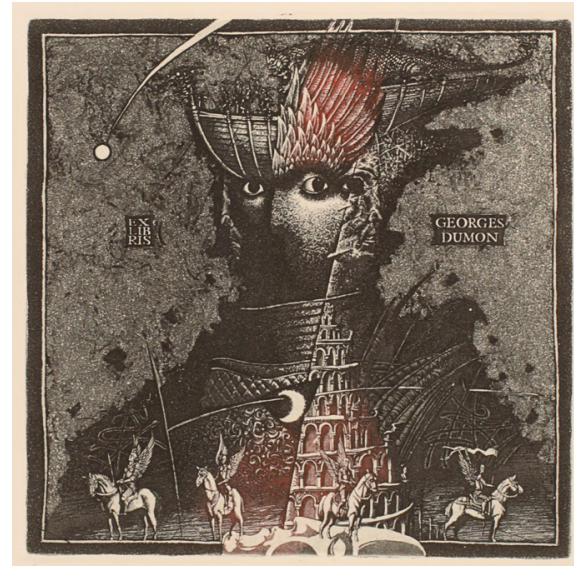

Figure 3: Designed by Roman Nikolaevich Sustov, aquatint and etching, $12,8 \times 11,9 \mathrm{~cm}$, Belarus, 2009 (Source: Frederikshavn Art Museum Collection)

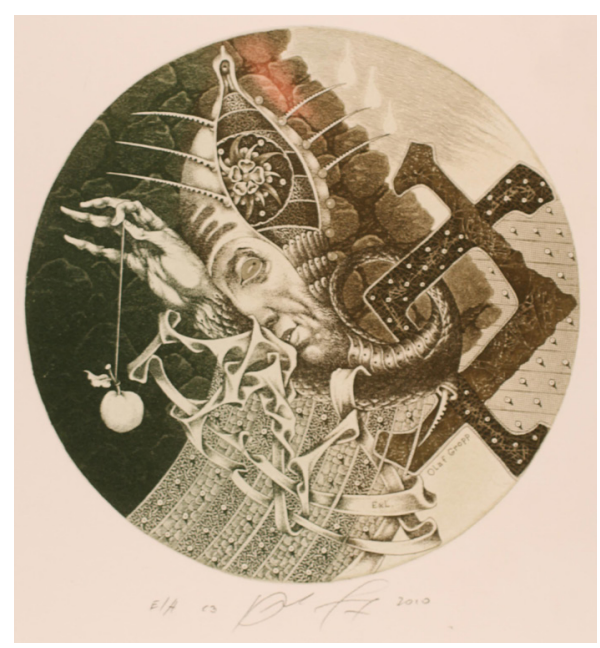

Figure 4: Jurij Jakovenko, $13 \times 12,3 \mathrm{~cm}$, Belarus, 2010 (Source: Frederikshavn Art Museum Collection) perfectly in the piece with great care. (See figure 2).

Towards the end of the 19th century, the art of ex-libris exceeded its sole meaning of determining the property of the book and began to gain value as a collection piece. The themes and narrative styles have been diversified, and the symbolic expressions of magnificence have left their place to narrative with natural content. "Ex-libris pieces, which are not just made with the thought of attaching to books and are used as objects of collection and exchange now, have detached from its original indication role for the book and became independent as a unique graphic work" (Pektaş, 2017, p.19).

Moving on to the 2oth century, the use of ex-libris continued to expand globally day by day with the influence of various international associations, international congresses, contests and exhibitions together with the printing artists sharing it among themselves.

From 200os to the present, in scope of a research on the analysis of use of portraits in ex-libris design, Frederikshavn Art Museum Exlibris Collections stand out as an efficient resource. The digital ex-libris museum (http:// art-exlibris.net), which contains a total of 450,000 artifacts dating back to 1700 s and including Hartvig Thomsen, Jensen Tusch, Johny Køhler, Klaus Rödel, P. Th. Albrechtsen and Wolfram Körner's collections, has also been scanned in scope of this research. In the museum collection, a total of 346 works, which were designed using portraits, were found in the period between the years 2000-2017. When these works were examined according to countries they come from, noteworthy distinguishing differences were spotted. Taking technical competence, original artistic expression language and visual components that make up the design into consideration, 16 works were selected to be examined in detail among 346 designs.

With great competence in engraving technique, Belarusian artists come to the forefront. Portraits adorned with fine details are interpreted by combining with fantastic creatures, and the stain values are strong in these works. An infinite fantasy world is designed with surrealistic epic narrative that is in perfect harmony with typographic elements. Expressions in portraits are mysterious, impressive and profound. (See figure 3-4).

Among the contemporary Italian artists, it is observed that the intaglio printing techniques are used widely and skillfully. Italian artist Luigi Casalino is an artist who has mastered the art of etching and obtained an original narrative language in use of portraits. His works that contain surrealist elements are quite detailed. Characteristic expressions in the portraits of

(c) 2018 EX-LIBRIST Part 8 - January 2018, Akçadoğan, “From 200os to the Present, Analysis of Use of Portraits in Ex-libris Design" 


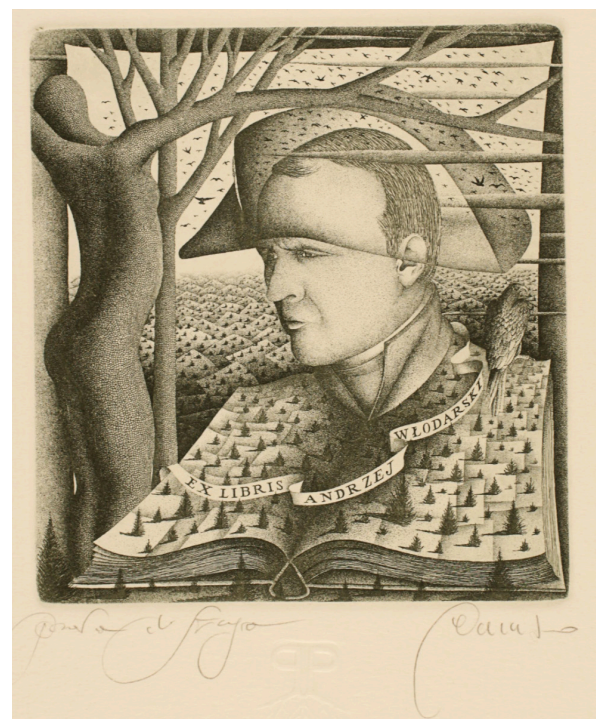

Figure 5: Pietro Paolo Tarasco, etching, Italy, 2000, (Source: Frederikshavn Art Museum Collection)

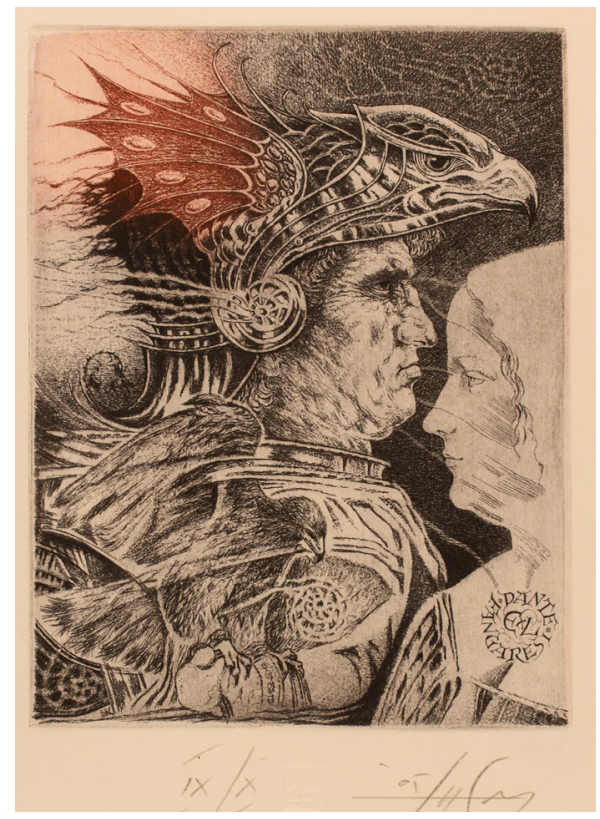

Figure 6: Luigi Casalino, etching, 17,4 × 12,6 cm, Italy, 2005 (Source: Frederikshavn Art Museum Collection)

his works are sometimes rigid as a sculpture, but the delicate and refined expression spread over the whole of the work creates a balance. It is observed that contrast is always paid attention to and mythological themes are used in the artist's works. (See figure 6-7).

Another contemporary Italian printmaker, Erica Forneris, seems to use etching technique in her works perfectly to create realistic photographic portraits. These works are inspired by everyday life and the effect of natural sunlight is emphasized with a realistic language.

Pietro Paolo Tarasco is also one of the original Italian printmakers who has been using the technique of etching with great skill. In most of his works, the images of trees are present with sculptural structures. The forms in the exlibris designs are processed with a graphical narrative. (See figure 5).

Another contemporary Italian printmaker Ivo Mosele, who stands out with his ex-libris works inclusive of portraits, has used a realistic narrative style in his engravings produced with mezzotint technique. Using the possibilities of mezzotint technique professionally, the artist has created photographically effective works with light shadow games. (See figure 8).

It is seen that most of the contemporary Italian ex-libris artists prefer traditional engraving techniques such as etching, mezzotint, drypoint and aquatint, and they have developed unique narrative languages in these techniques. Maria Maddalena Tuccelli and Paolo Rovegno among today's prominent artists, also have an important role in Italian ex-libris art with

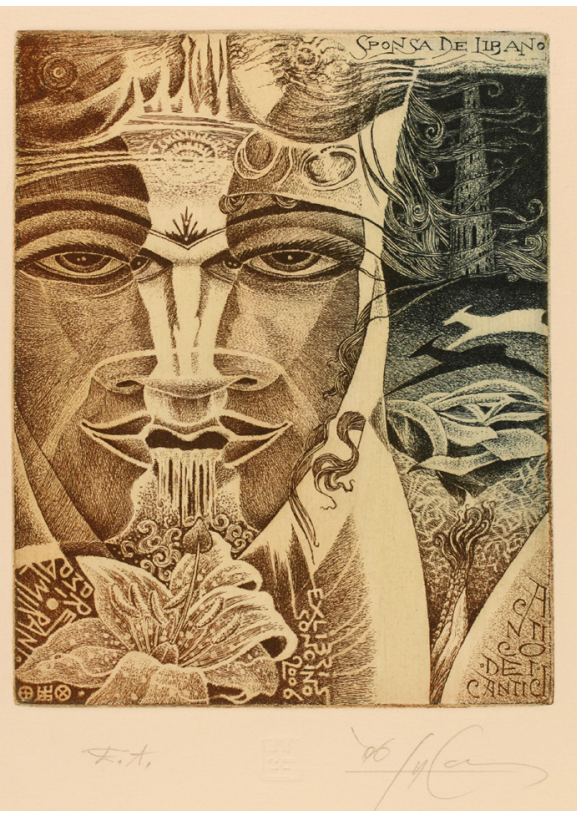

Figure 7: Luigi Casalino, etching, 19,1 x 13,7 cm, Italy, 2005 (Source: Frederikshavn Art Museum Collection)

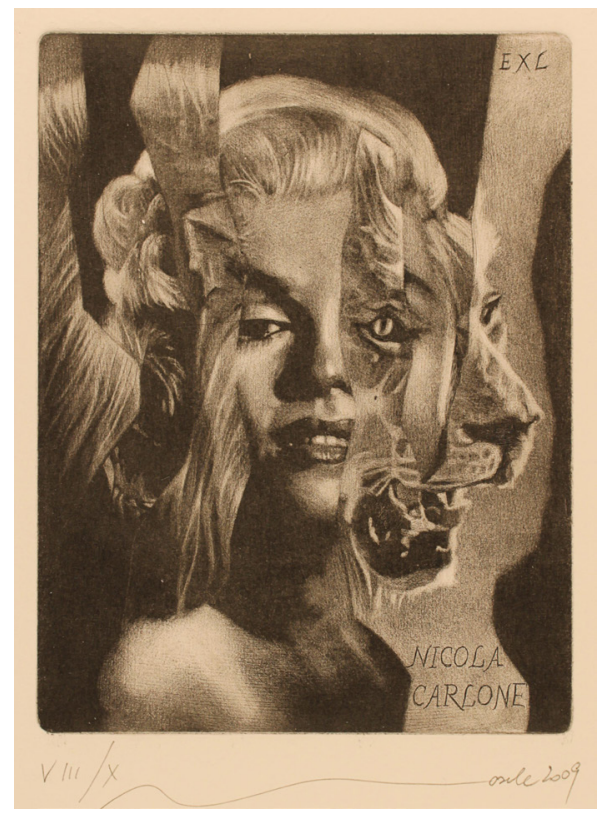

Figure 8: Ivo Mosele, mezzotint, Italy, 2009 (Source: Frederikshavn Art Museum Collection) 


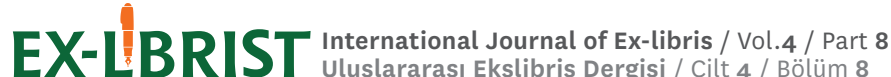

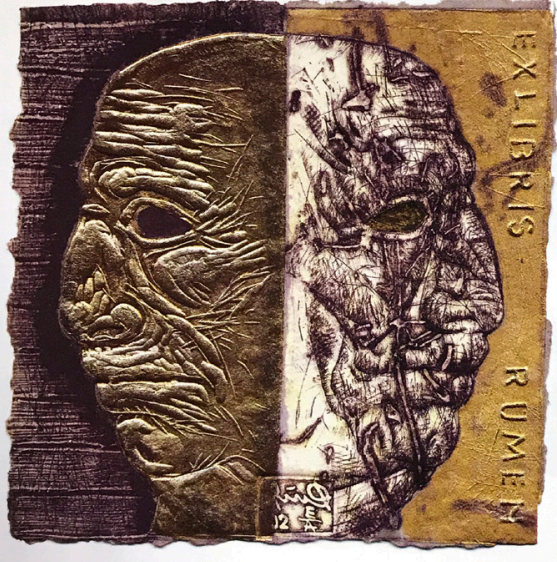

Figure 9: Rumen Netschev, mixed technique, Bulgaria, 2002 (Source: Hacettepe University / AED (2003) 1st Exlibris Competition Exhibition Catalogue, Ankara)

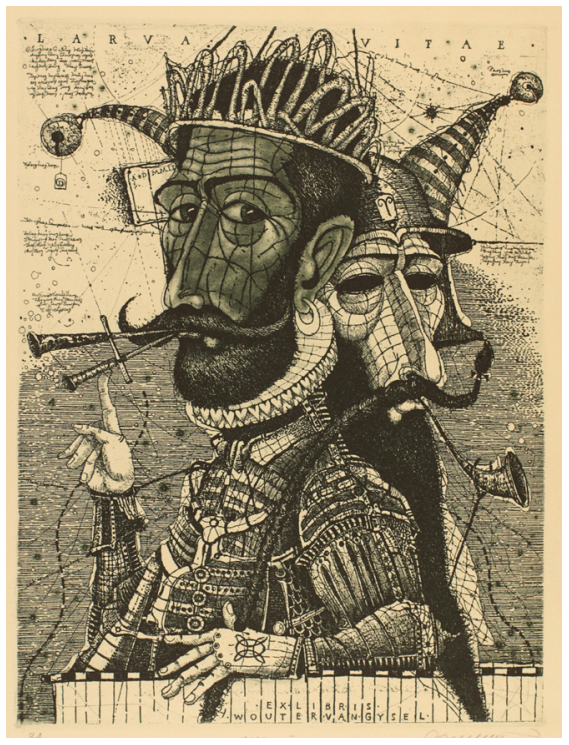

Figure 10: Oleg Denisenko, mezzotint, etching, drypoint, Ukraine, 2002 (Source: Frederikshavn Art Museum Klaus Rödel Collection)

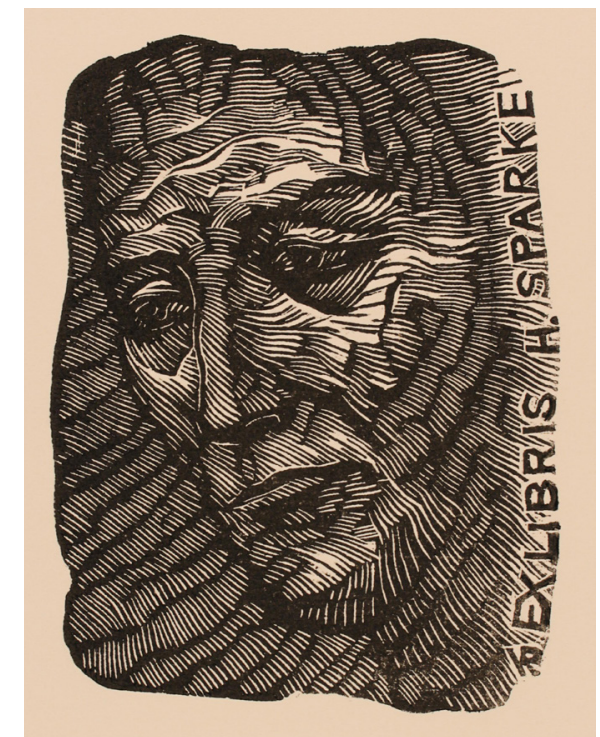

Figure 11: Ruslan Vigovsky, wood engraving technique, Ukraine, 2002 (Source: Frederikshavn Art Museum Collection)

their portrait-based designs.

In the post-200o period, when the works of Ukrainian printmaker Oleg Denisenko are examined, it is seen that the artist uses traditional intaglio printing techniques together with a humorous style of expression.

Characterized portraits are enriched with the unique fantasy world of the artist. (See figure 10).

Surreal and fantastic elements also have an important role in the works of Ukrainian artists. In the use of portraits, it is seen that the characteristic figures are used together with a unique language within graphic expressions. Sergei Hrapov, David Bekker, Konstantin Kalynovych and Sergey Kirnitsky, who produced works after the 2000s, are influential ex-libris artists who used techniques of intaglio. Another Ukrainian artist Ruslan Vigovsky, who has worked predominantly in the field of wood engraving printing, has captured unique expressions in portraits. The artist also has works produced by computer-based design technique (CGD). (See figure 11).

Bulgarian artists also have a significant place in the field of graphic arts. Unique, deep and original artworks are delicate and detailed as a paper nautilus shell. Figures and portraits are extraordinary and exclusive. 1st International Exlibris Competition (Ankara, 2003) first prizewinner Julian Dimitrov Jordanov is also among these major artists. In the works of Veselin Damyanov-ves, who is prominent contemporary printmaker from Bulgaria, portraits are included in the design through etching, linoleum printing 


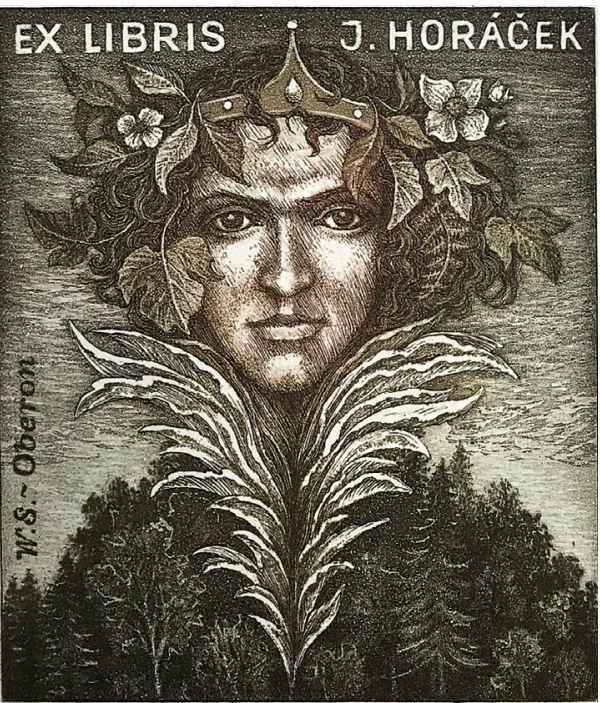

Figure 12: Peter Melan, etching and aquatint, Czech Republic, 2002 (Source: Hacettepe University / AED (2003) 1st Exlibris Competition Exhibition Catalogue, Ankara)

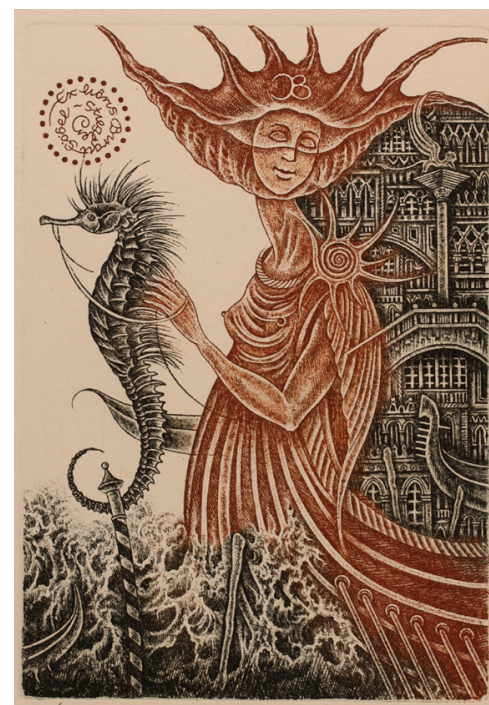

Figure 13: Natalija Chernetsova, etching and aquatint, Letonia, 2007 (Source: Frederikshavn Art Museum Collection)

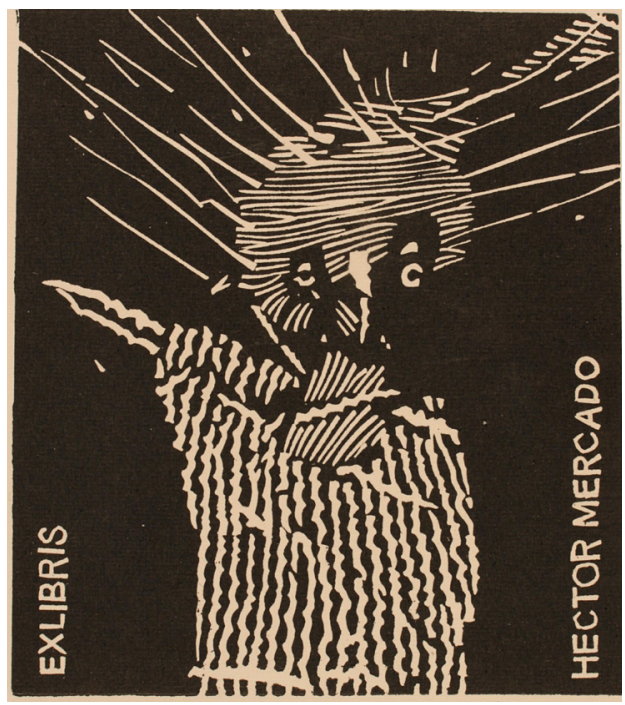

Figure 14: Lukasz Cywicki, linoleum print, Poland, 2011 (Source: Frederikshavn Art Museum Collection)

technique and mixed techniques. Another Bulgarian artist Rumen Netschev also uses mixed technique in his works. The artist was selected for the exhibition of 1st International Exhibition of Exlibris Competition held in Ankara in 2003 with his imposing portrait work. In his impressive and tense works, expression has been made stronger with color choice and negativepositive relationship. (See figure 9). Among the influential contemporary Bulgarian artists, who use etching techniques in their portrait-oriented work, are Peter Velikov, Hristo Naidenov and Edward Penkov, who died in 2016 at a young age.

Among printmakers from Czech Republic in the post-200os, Peter Melan (See figure 12), Günter Hujber, Oldrich Kulhánek, Marina Richter, Renata Simlikova, and Jiri Brazda, who stand out with their designs including portraits, have often produced works with intaglio techniques. Another important Czech artist, Vladimir Suchanek, is a master of lithography technique. Expressions in the eyes of portraits that stand out in terms of stain value in the artist's composition are dramatic and mysterious.

In the post-2000 period, works of Latvian artist Natalija Chernetsova, who grabs attention with a unique style, were produced with etching and drypoint techniques. Within the details of the sepia-toned works, intertwined fine points together with nature, figures, textures and architectural elements create a fascinating atmosphere. The fairy-tale like interpretations are quite rich in patterns. (See figure 13).

From Poland -the center for prominent graphic artists- Arkadius Burda, 


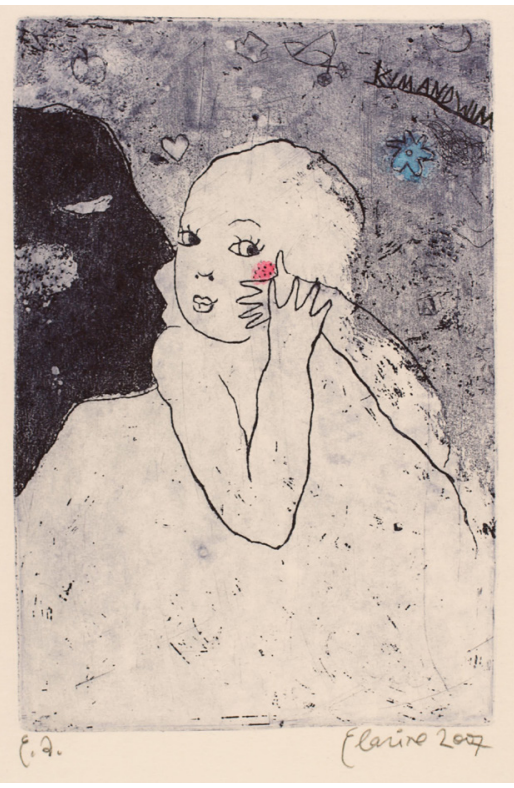

Figure 15: Irina Yelagina, etching, Russia, 2007 (Source: Frederikshavn Art Museum Collection)

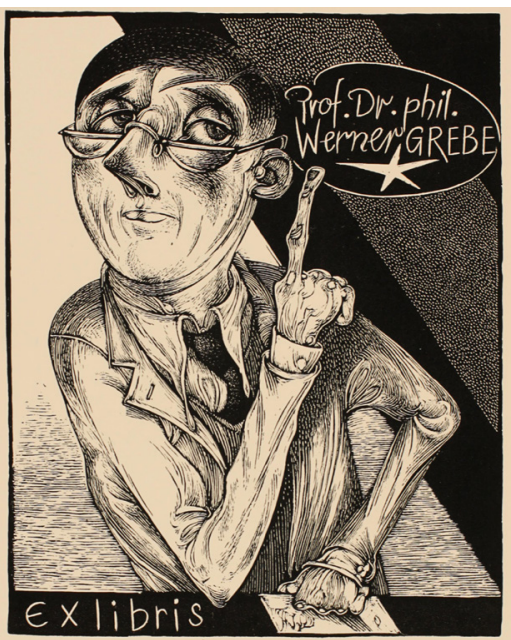

Figure 16: Karl Georg Hirsch, relief printing - other materials, Germany, 2000 (Source: Frederikshavn Art Museum Klaus Rödel Collection)
Lukasz Cywicki (See figure14) and Zbigniew Jozwik have created powerful original graphic-artworks using mainly relief printing techniques. Ewa Kutylak, Piotr Gojowy and Hanna T. Glowacka produced intaglio prints, whereas Wojciech Luczak uses intaglio and relief printing techniques, and Weroniki Podstawki produced various works in engraving, linoleum printing and computer-based design (CGD) techniques in the post-2000 period.

In the post-2000 period, Russian printmakers that catch the eye with portrait works are M. M. Vercholantsjew who works with wood carving printing technique, wood printing and linoleum printing techniques; and Vladimir Zuev who works with etching and mezzotint techniques. Irina Yelagina has captured a modern and graphical language with her unique style of etching. The artist obtains negative-positive effects with the backgrounds prepared with typographic elements. The expressions in the figures are pure and simple. (See figure 15).

In the post-200o period, when the works of the German ex-libris artists are examined, technical diversity attracts attention. Hans-Gerhard Blödorn, Andreas Raub, Norbert Salzwedel, who work with etching; Olaf Gropp and Kay Voigtmann who work with aquatint and etching; Annette Fritzsch who makes works with transfer lithography printing, linoleum and mixed technique; Karl Georg Hirsch (See figure 16), who has skillfully mastered the use of plastic engraving and relief printing techniques, are among German artist that capture authentic styles in portrait work.

Hedvig Pauwels and Antoon Vermeylen are significant among the Belgian ex-libris artists who are prominent with their portrait designs. Hedvig Pauwels has skillfully used etching technique to create realistic expressions

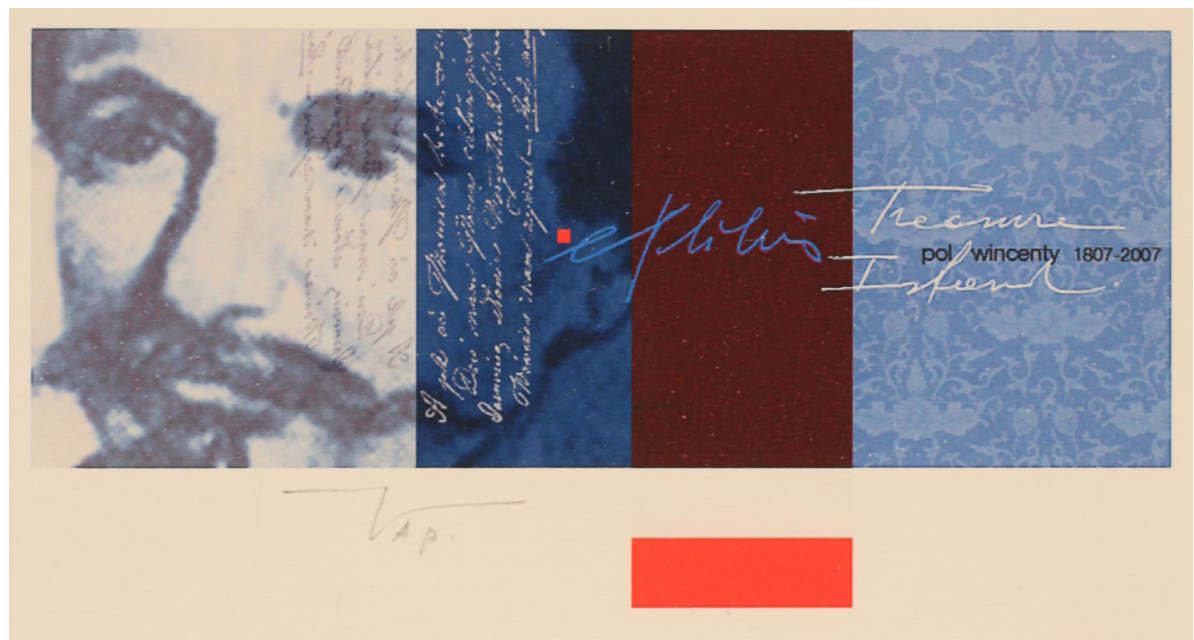

Figure 17: Martin R. Baeyens, computer based design, 4,6 x 8,5 cm, Belgium, 2007 (Source: Frederikshavn Art Museum Klaus Rödel Collection) 


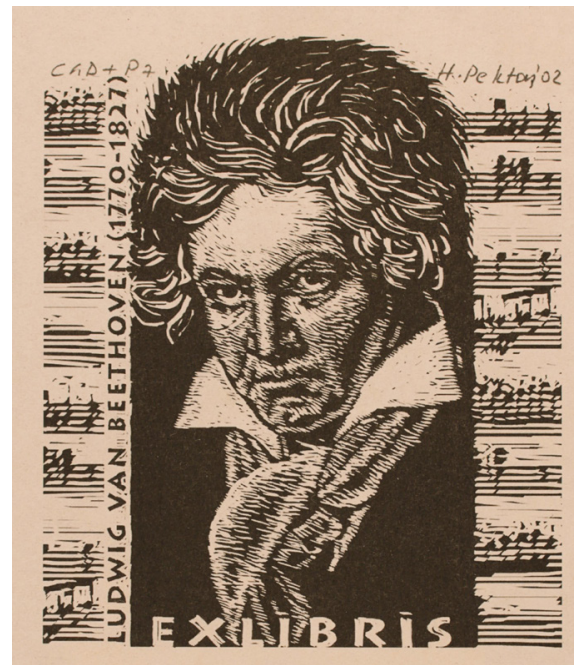

Figure 18: Hasip Pektaş, (Universal Exlibris) computer based design and offset printing CGD+P7, 9,5 × 7,9 cm, Turkey, 2002 (Source: Frederikshavn Art Museum Collection) in portraits. In the works of Martin R. Baeyens, a Belgian artist born in 1943, it is observed that a variety of printing techniques are used. In addition to traditional printing techniques, the artist who produces works with the computer-based design technique preserves his integrity of expression in these artworks produced by the facilities of the new technology after 2000s. (See figure 17). Modern graphic color schemes, typography elements and antiquated surfaces are included in the ex-libris artworks which, in a manner, reflect the 500-year history of ex-libris design from past to present.

With his contributions to Turkish ex-libris designs and his leading role, the academician Professor Hasip Pektaş is among Turkey's most prominent exlibris artists. By teaching countless students, who were interested in ex-libris design; and by becoming successful in important national and international events, he has been a pioneer in the emergence and widespread of exlibris in Turkey while inspiring new artists to emerge. In addition to using a variety of traditional printing techniques in his work with a unique narrative language, he draws attention with his works completed using computerbased design techniques (CGD). (See figure 18).

There are also works by the artist, many of which are reproduced by the artist, whose name is left blank; and these are described as "universal ex-libris", usually designed in the form of offset printing and labeling and massed produced for people to put their own name on and use them (Pektas, 2017, p.47).

When Turkish artists who have included portraits in post-2000 period exlibris are researched, it is seen that most of the young artists prefer to apply computer-based design (CGD) compared to others who use traditional printing techniques. Although the history of ex-libris in Turkey does not go back much, it is possible to talk about the presence of a large community of young artists who continue to experiment with new pursuits.

\section{Conclusion}

In the 500-years-old historical process of printed ex-libris designs, portraits have been frequently used as an element that constitute the artwork inline with the ex-libris' function of being an artistic register for the book. In the Frederikshavn Art Museum Exlibris Collection, in the post-2000 period, among the 346 works produced with emphasis on portraiture use and of which the making techniques were determined, $30 \%$ were made using etching technique ( $\left.\mathrm{C}_{3}\right), 7 \%$ aquatint technique ( $\left.\mathrm{C}_{5}\right), 6 \%$ linoleum printing technique ( $\mathrm{X}_{3}$ ) (Linocut), 6\% was made using burin engraving on copper technique ( $\mathrm{C}_{2}$ ) (Burin engraving), $5 \%$ were computer generated design 
(CGD), 4\% mezzotint (C7), $2 \%$ drypoint technique (C4), $2 \%$ mixed technique (M.T), $2 \%$ line block technique $(\mathrm{P} 1), 1.5 \%$ wood engraving $\left(\mathrm{X}_{2}\right), 1.5 \%$ relief printing - other materials (X6), $0.5 \%$ silk screen printing (S1) and $0.5 \%$ Photo (P8) (original photograph, hologram) were used. It is observed that today, European artists generally prefer traditional printmaking techniques, but artists from countries such as Poland, Belgium, Ukraine and Turkey, have been performing research with new technologies (CGD) and have been producing computer-based works. Techniques (intaglio, relief printing, reprinting, flat, template and electronic printing methods) in this functional art field, which has arrived from the past to today, are tools that strengthen the expression of the artist.

As a result of the analysis of works selected for this research, it was observed that while the artists developed expression methods appropriate to their own artistic expression language, they showed similarities with their contemporaries in the cultural geography they are located in terms of technique and form.

With the development of technology, the creation of an unlimited structure of communication around the world and with the dedicated print artists preparing various sharing environments, interest in this branch of art is increasing and all these developments play a major role in the emergence of new ex-libris artists.

\section{Resources}

FISAE International Federation of Ex-libris Societies. Retrieved on: 07.12.2017 http://www.fisae.org/whatareex.html

Frederikshavn Sanat Müzesi Koleksiyonu. Retrieved on: 07.12.2017 http://artexlibris.net

Hacettepe Üniversitesi / AED. (2003). 1st Exlibris Competititon Exhibition Catalogue Ankara

Heinemann, Dr. O. Von. (1895). The Ex-Libris Collection of the Ducal Library At Wolfenbüttel. London

Kırışoğlu, O.T. (2014). Ekslibrisin Üç Yönü: Bir Sanat Eseri, İşlevsel Bir Nesne, Bir Eğitim Konusu. EX-LIBRIST Uluslararası Ekslibris Dergisi, IED. Retrieved on: 06.12.2017 http://exlibrist.net/index.php/exlibrist/article/view/10 
Pektaş, H. (2015). Ekslibris Nedir?, istanbul Ekslibris Derneği. Retrieved on: 07.12.2017 http://www.aed.org.tr/tr/ekslibris/

Pektaş, H. (2014). Türkiye'de Ekslibris. EX-LIBRIST Uluslararası Ekslibris Dergisi, IED. Erişim: 08.12.2017 http://exlibrist.net/index.php/exlibrist/ article/view/8 Pektaş, H. (2015). Ekslibrisin Tarihi Gelişimi. İstanbul Ekslibris Derneği. Retrieved on: 07.12.2017 http://www.aed.org.tr/tr/ekslibris-tarihi/

Royal Collection Trust. Published Jun 2011. Retrieved on: 08.12.2017 https:// www. royalcollection.org.uk/collection/800112/willibald-pirckheimer

\section{Further Sources}

http://www.bookplate.org/

http://www.hasippektas.com/

https://www.exlibris-selc.ch 